\title{
Masalah Kemitraan dalam Pembinaan Industri Kecil
}

\author{
Oleh Arief Ramelan Karseno
}



\section{Pendahuluan}

Pertumbuhan ekonomi di Indonesia di masa datang sangat tergantung pada pengembangan dan pertumbuhan sektor industri, khususnya industri manufaktur, mengingat bahwa dalam waktu yang relatif dekat Indonesia akan menjadi net-importer di sckior minyak. Sedangkan pertumbuhan sektor industri di suatu negara, pada umumnya berkaitan erat dengan peran industri kecil di negara itu. Pada umumnya, negara yang memiliki sektor industri manufaktur yang kuat, memiliki industri kecil yang sangat berperan di dalam negeri. Besar atau kecilnya peran industri kecil di dalam struktur industri suatu negara, sangat ditentukan oleh pola kebijaksanaan industrialisasi yang diambil olch pemerintah negeri itu. Sebagai ilustrasi, atijgka yang menggambarkan peran industri kecil pada berbagai negara di wilayah Asia-Pacific, dapat dilihat pada tabel 1 .

\section{Kebijaksanaan Industrialisasi}

Secara teoritis ada tiga kelompok besar konsep pembangunan ekonomi, dengan memanfaatkan sektor industri motor utamanya. Yảng pertama adalah konsep comparatice advantage, dimana sektor industri yang diprioritaskan adalah sektor-sektor yang memiliki keunggulan relatif (khususnya tenaga kerja) yang terbesar. Yang kedua adalah konsep pembangunan dengan loncatan teknologi ke depan. Dalam hal investasi besar-besaran harus dilakukan untuk menemukan suatu pola produksi yang memiliki nilai tambah faktor produksi yang tinggi. Konsep yang ketiga adalah konsep industri dengan memperhatikan masalah linkage.
Pengembangan industrialisasi dengan pola ini, mengarahkan pertumbuhan industri dengan prioritas. pada sektor-sektor yang memiliki keterkaitan industri yang besar.

Tabel 1

Peran Industri Menengah dan Kecil (SME) di negaranegara APEC

\begin{tabular}{|c|c|c|c|}
\hline Negara & $\%$ SME & $\begin{array}{l}\text { \% Penyerapan } \\
\text { Tenaga Kerja }\end{array}$ & $\%$ Sales \\
\hline $\begin{array}{l}\text { Australia } \\
\text { Bnunei } \\
\text { Canada } \\
\text { RRC } \\
\text { Hong Kong } \\
\text { Indonesia } \\
\text { Japan } \\
\text { Malaysia } \\
\text { Mexico } \\
\text { New Zealand } \\
\text { Philippine } \\
\text { Cina Taipeh } \\
\text { Thailand } \\
\text { USA }\end{array}$ & $\begin{array}{c}95 \% \\
\text { (thn.1991-1992) } \\
>90 \% \\
99.8 \% \\
\text { (thn.1992) } \\
\\
97.95 \% \\
\text { (thn.1993) } \\
97 \% \\
\text { (thn.1993) } \\
99.1 \% \\
\text { (thn.1991) } \\
\\
98.17 \% \\
\text { (thn.1993) } \\
\\
9.22 \% \\
\text { (thn.1991) } \\
96.77 \% \\
\text { (thn.1991) } \\
98.63 \% \\
\text { (thn.1991) } \\
99.72 \% \\
\text { (thn.1990) }\end{array}$ & $\begin{array}{c}39.6 \% \\
\text { (thn. 1991-1992) } \\
69.4 \% \\
59.24 \% \\
\text { (thn.1991) } \\
84.27 \% \\
63 \% \\
\text { (thn. } 1993 \text { ) } \\
67 \% \\
\text { (thn. } 1986) \\
79.2 \% \\
\text { (thn.1991) } \\
\\
50.77 \% \\
\text { (thn.1993) } \\
\\
32 \% \\
\text { (thn.1991) } \\
68.63 \% \\
\text { (thn.1992) } \\
73.80 \% \\
\text { (thn.1991) } \\
53.67 \% \\
\text { (thn. } 1990 \text { ) }\end{array}$ & $\begin{array}{c}33.66 \% \\
\text { (thn.1992) }\end{array}$ \\
\hline
\end{tabular}

Sumber: Tjakrawerdaya, S. 1994

Masing-masing pola pengembangan industrialisasi tersebut diatas, memiliki keunggulan dan 
kelemahannya sendiri-sendiri. Pola yang pertama memiliki kelemahan, yaitu bahwa sektor-sektor yang unggul adalah sektor-sektor pertanian saja, karena pengalaman produksi di sektor ini sudah cukup lama. Keunggulan comparative muncul sebagai akibat tingginya efisiensi produksi suatu komodity. Oleh karena itu sektor-sektor yang memiliki keunggulan comparative yang tinggi adalah sektor yang 'mature' di dalam tahapan produksinya. Sebagai akibatnya, sektor-sektor industri yang relative baru tidak mungkin tergolong sebagai sektor yang memiliki comparative advantage. Hal ini akan merugikan perkembangan industri di dalam jangka panjang.

Model industrialisasi yang kedua adalah, dengan Ioncatan teknologi, akan menguntungkan term of trade sektor industri di dalam jangka panjang. Nilai tambah sektor industri akan menjadi sangat tinggi, karena sektor itu akan mampu mengembangkan jenis produksi yang dibutuhkan dan relatif langka. Apabila hal ini mampu dilakukan, maka perekonomian nasional akan melaju dengan kecepatan yang cukup pesat. Salah satu kelemahannya adalah, tingginya angka ketidak pastian untuk sukses, dan tingginya biaya yang harus dikeluarkan di dalam jangka pendek. Defisit anggaran pada tahuntahun pertama program akan menjadi kẹndala utama pola industrialisasi ini.

Yang ketiga adalah model industrialisasi dengan memperhatikan linkage atau struktur keterkaitan. Model ini mengharuskan adanya prioritas pengembangan industri yang memiliki keterkaitan yang paling besar, baik ke depan maupun ke belakang. Salah satu keunggulan model ini adalah banyaknya pihak yang bisa terlibat dalam pengembangan. Model ini biasanya dipilih apabila pengambil keputusan bermaksud untuk meningkatkan pemerataan hasil dari proses industrialisasi. Disamping itu, model linkage ini juga bermanfaat untuk pengembangan industri $\cdot$ substitusi import. Dilain pihak, kelcmahan model ini antara lain adalah bahwa pengembangan industri kadang-kadang tidak memperhatikan masalah efisiensi. Industri dikembangkan dan dibina hanya atas dasar adanya keterkaitan dengan industri yang sudah ada. Dengan demikian, pengentbangan industri seringkali harus melibatkan proteksi dari pemerintah, yang secara langsung akan merugikan konsumen. Pcrilaku dan kehendak produsen, khususnya pada indusiri hulu, rclatif diabaikan, sehingga muncul berbagai masalah ditingkat implementasi.

\section{Industri Kecil di Indonesia}

Pola pengembangan industri dengan metoda keterkaitan adalah salah satu model pengembangan industri yang. dianut Departemen Perindustrian RI. Metoda ini dipilih, antara lain untuk membantu mengembangkan sektor industri kecil dan rumah tangga. Program pengembangan industri kecil ini dilaksanakan sebagai bagian dari program pemerataan hasil pembangunan, dan sekaligus merupakan program pengentasan kemiskinan di Indonesia.

Dilihat dari definisi BPS, industri kecil adalah perusahaan yang memperkerjakan buruh antara $5 \mathrm{~s} / \mathrm{d} 19$ orang, sedangkan industri rumah tangga adalah perusahaan dengan 4 orang tenaga kerja atau kurang. Istilah industri kecil pada paper ini merujuk pada definisi industri kecil dan industri rumah tangga versi BPS. Dari catatan sensus Industri 1986, diketahui bahwa industri kecil dan industri rumah tangga merupakan sektor-sektor diluar sektor pertanian yang paling banyak menyerap tenaga kerja. Dari sejumlah 60 juta pekerja di sektor manufakturing pada tahun 1986, sekitar.67 persen lebih diserap oleh sektor industri kecil dan rumah tangga.

Secara konseptual, pengembangan industri dengan metoda keterkaitan dapat diharapkan untuk mengangkat industri kecil menjadi industri sedang atau besar dalam waktu singkat. Salah satu syarat berhasilnya tujuan itu adalah apabila sektor industri kecil memiliki keterkaitan dengan usaha scktor industri besar baik secara langsung maupun tidak. Dengan cara ini nilai kandungan import sctiap hasil produksi akhir dapat dikurangi semaksimal mungkin. Dan usaha menuju pada kemandirian industri dapat diwujudkan. Dengan kata lain, melalui program kctcrkaitan ini diharapkan juga adanya pengembangan industri substitusi import untuk tujuan ikut mengurangi defisit neraca berjalan.

\section{Bapak - Anak Angkat (BAA)}

Dengan berpedoman pada konsep tersebut di atas, pemerintah mengembangkan suatu kebijaksanaan yang dimaksudkan untuk memajukan industri-industri di Indonesia. Kebijaksanaan untuk itu dituangkan pada program Bapak-Anak Angkat, yaitu dimulai sejak Peraturan Pemerintah nomor 3 tahun 1983. Peraturan ini dimaksudkan untuk mendorong perusahaan-perusahaan Besar BUMN dan BUMS untuk berperan aklif ikut mengembangkan industri kecil melalui program ketcrkaitan ini.

Berdasarkan PP nomor 3 tahun 1983 itu, Departemen Perindustrian menindak lanjuti dengan mengeluarkan Instruksi Menteri Pcrindustrian no. 301/ $\mathrm{M} / \mathrm{SK} / 8 / 1984$, yảng pada pokoknya menyatakan baḥwa Departemen Perindustrian ' bertugas untuk mempromosikan program keterkaitan antara pengusaha besar dan pengusaha kecil melalui: (1) hubungan subcontracting, dan (2) hubungan Bapak-Anak Angkat.

Hubungan subcontracting adalah hubungan antära BUMN atau perusahaan besar lainnya dengan perusahaan kecil dalam bentuk pemesanan suku cadang 
atau komponen (part) produksi akhir. Sedangkan hubungan Bapak-Anak Angkat (BAA) adalah bentuk pengembangan pengusaha kecil oleh perusahaan besar melalui hubungan mitra dagang, atau sebagai pemasok kebutuhan operasional pengusaha besar. Bentuk-bentuk bantuan pengusaha besar kepada pengusaha kecil tidak dibatasi dalam bentuk mitra dagang saja, tetapi bisa juga di dalam bentuk pembinaan yang lain.

Program keterkaitan antara Pengusaha Bèsar dengan Pengusaha Kecil dan Menengah ini menjadi lebih penting setelah dikeluarkan Undang-undang R.I. No. 5 tahun 1984 tentang Perindustrian. Sejak dikeluarkannya UU ini, maka berarti pola keterkaitan sudah dinyatakan sebagai pola umum perindustrian di Indonesia.

\section{Manfaat, Kerugian dan Permasalahan Program Keterkaitan}

Seperti telah dibahas di atas, program keterkaitan memiliki beberapa keunggulan dan kelemahan. Keunggulannya adalah adanya pemerataan partisipasi kegiatan industri pada semua level masyarakat. Kelemahan yang menonjol adalah munculnya proteksionisme pada industri yang tidak kompetitif. Kelemahan ini dapat dianggap kecil atau bisa diabaikan apabila pola keterkaitan ini mampu menghasilkan pemerataan partisipasi berproduksi bagi industri-industri kecil. Karena kita menyadari sepenuhnya bahwa pemerataan pembangunan khususnya di sektor perindustrian memerlukan usaha dan biaya yang tidak kecil. Namun demikian permasalahan yang muncul di dalam program pemerintah ini terutama pada lingkat teknis pelaksanaan.

\section{Manfaat Program Keterkaitan Bagi Pengusaha Kecil}

Pengusaha kecil memiliki tiga masalah utama, yaitu: (1) modal, (2) ketidak pastian pasar dan (3) standardisasi produksi. Ketiga masalah ini adalah masalah klasik industri kecil yang secara teoritis akan mampu diatasi dengan adanya program Bapak-Anak Angkat.

Dengan program BAA, ini masalah permodalan pengusaha kecil dapat diselesaikan a.l. dengan memanfaatkan dana bantuan yang berasal dari $1 \mathrm{~s} / \mathrm{d} 5$ persen laba BUMN. Dengan adanya program BapakAnak Angkat persoalan permodalan yang umumnya dihadapi oleh pengusaha kecil dapat diselesaikan dengan bantuan pengusaha besar. Misalnya, apabila pengusaha kecil mengalami kesulitan mendapatkan reference untuk memperoleh modal dari institusi formal seperti bank, maka Bapak Angkat bisa membantunya.

Ketidak pastian pasar juga merupakan salah satú permasalahan yang dihadapi pengusaha kecil. Apabila program BAA bisa dilaksanakan dengan baik, pengusaha kecil akan mendapatkan manfaat karena ia bisa memperoleh quota produksi atau porsi kontrak yang pasti selama satu periode tertentu. Dengan demikian mereka tidak perlu khawatir mengenai kelangsungan penjualan hasil produksinya.

Permasalahan lain yang bisa diselesaikan dengan sistem linkage ini ialah masalah standardisasi. Pengusaha kecil selalu mengalami masalah didalam stadardisasi kualitas. Ada dua macam standard yang perlu diperhatikan didalam pengembangan industri, yaitu standard dalam teknik produksinya dan standard dalam hal ke-ajeg-an kualitasnya. Dua hal ini biasanya saling terkait satu sama lainnya. Peningkatan teknik produksi akan meningkatkan kualitas hasil dan sekaligus mengecilkan variasi qualitas. Dengan bantuan industri besar berupa training atau bantuan supervisi akan sangat membantu pengusaha kecil meningkatkan kapasitas dan qualitas produksinya.

\section{Kerugian Program Keterkaitan (BAA) bagi Industri Kecil}

Meskipun secara umum terdapat manfaat dari program Bapak-Anak Angkat, ada juga kerugian yang harus diderita olch industri kecil dari program ini.

\section{Ketergantungan}

Dengan membiasakan diri tergantung pada satu pembeli secara terus-menerus, produsen memiliki kecenderungan menjadi manja dan tidak bisa bersaing. Mereka terpaksa meninggalkan kebiasaan mengambil keputusan di dalam bidang pemasaran. Padahal di dalam jangka panjang, keputusan bidang pemasaran ini akan menjadi ujung tombak pengembangan industri. Disamping itu, apabila secara tiba-tiba si Bapak Angkat menghentikan pembeliannya karena faktor-faktor extemal, maka penusahaan kecil mengalami kesulitan untuk terus hidup, karena tidak mampu lagi mencari pasamya sendiri.

\section{Exploitasi}

Dengan adanya bentuk integrasi vertikal yang disengaja ini, pasti ada korban yang muncul. Salah satu korban adalah produsen di level bawah, yaitu pengusaha kecil. Pola pembagian keuntungan pada vertikal integrasi ini, -- karena memiliki struktur "single buyer" --, maka pada umumnya lebih menguntungkan produsen hilir daripada hulu. Oleh karena itu pengusaha kecil pemasok, akan menderita, karena terjadi exploitasi oleh pengusaha besar yang merupakan Bapak Angkatnya melalui mekanisme penetapan harga jual produk. Sistem harga yang ditetapkan, dalam banyak kasus lebih rendah daripada harga pasar, karena alasan kualitas dan 
kontinuitas hubungan produksi.

\section{Permasalahan pada Program Linkage}

Selain manfaat dan kelemahannya, program Bapak-Anak Angkat ini memiliki banyak sekali permasalahan, khususnya apabila dilaksanakan di lapangan. Permasalahan atau hambatan itu pada umumnya berkaitan dengan aspek kelembagaan.

Konsep linkage atau BAA yang tidak didasarkan atas minat atau keinginan perusahaan besar untuk membangun dasar industri domestik yang luas, tidak akan menghasilkan sesuatu yang menguntungkan bagi kedua belah pihak. Namun demikian kerugian biasanya jatuh pada pihak pengusaha kecil (AA).

Perusahaan dengan skala ekonomi yang besar akan cenderung memiliki teknik produksi dan pola hubungan dengan mitra bisnis yang lebih efisien dibanding dengan perusahaan dengan skala ekonomi kecil. Variabel keputusan yang menjadi perhatian bisnis besar biasanya lebih banyak mengabaikan faktor detail yang bersifat variasi individual. Manajer pada perusahaan besar sering kali lebih memilih biaya minimal jangka pendek dari pada pengembangan hubungan industri jangka panjang, karena tuntutan pembayaran hutang kapital yang besar. Pembinaan industri kecil di dalam line of basisnya seringkali justru dilihat sebagai ancaman bagi perluasan pasamya sendiri, terutama apabila industri kecil itu berada diluar kontrolnya.

Dalam beberapa hal, perusahaan dengan skala besar seringkali merasa lebih efisien membeli faktor produksi dari luar negeri daripada membantu mengembangkan industri kecil pemasok komponen (part) domestik yang sebenamya mampu membuat komponen (part) sendiri. Hal ini sangat sering terjadi di bidang industri teknologi linggi seperti komputer dan elektronik.

Secara umum dapat dikatakan bahẉa suatu perusahaan besar yang melakukan usaha di dalam negeri dengan melewati proses mulai dari sejak industri itu masih kecil akan lebih mudah memberikan bantuan kepada Anak Angkatnya daripada industri yang dibangun langsung dengan modal raksasa dan tidak memiliki industrial base di dalam negeri. Pola pengambilan keputusan kedua jenis industri ini akan berbeda.

Masalah lain yang muncul dari program BAA ini ialah bahwa tidak semua industri kecil memiliki line bisnis yang sama dengan industri besar. Oleh karcna itu keharusan mengambil Anak Angkat mengakibatkan besamya angka kegagalan penciptaan linkage ini. Sering juga terjadi penunjukan Bapak-Anak Angkat secara sembarangan, demi pemenuhan target pemerintah (10.000 Anak Angkat di akhir Pelita ke V).

\section{Liberalisasi Perdagangán Bagi Industri Kecil}

Dengan disetujuinya perjanjian perdagangan multilateral GATT, putaran Uruguay pada akhir tahun 1993 lalu, tentu akan memiliki dampak kepada industri di Indonesia, khususnya industri kecil.

Perjanjian GATT adalah perjanjian antar pemerintah negara-negara di dunia. Kepentingan pemerintah antar negara ini adalah meningkatkan nilai perdagangan antar negara yang mereka pimpin. Sementara bisnis, khususnya bisnis kecil tidak memiliki kepentingan langsung dengan perjanjian perdagangàn antar negara ini. Sehingga secara organisational, sebenamya terdapat perbedaan kepentingan antar bisnis kecil dengan pemerintah.

Pemerintah berkepentingan dengan peningkatan investasi, guna mencapai target pembangunan, berupa pertumbuhan sebesar $6,2 \%$ setahun. Investasi domestik maupun investasi asing, bagi pemerintah tidak tampak ada perbedaan yang berarti. Perbedaan yang penting bagi "decision maker" adalah besar atau kecilnya skala usaha dan investasi. Sehingga, apabila dihadapkan pada pilihan usaha besar-asing/domestik atau usaha kecildomestik, pola pikir pembangunan yang dipakai oleh para pengambil keputusan akan berpihak kepada usaha besar baik asing maupun domestik. Oleh karena itu, dimasa datang, deregulasi yang berkaitan dengan pengembangan industri kecil diduga tidak akan terlalu berarti bagi kepentingan pengusaha kecil.

Dengan situasi tersebut, pengusaha kecil harus sadar sepenuhnya, bahwa dunia usaha kecil tidak bisa terlalu banyak mengharapkan bantuan pembinaan dari pemerintah. Dunia usaha kecil hanya bisa maju apabila diantara mereka mampu menciptakan "net-work" yang mandiri. Keterkaitan yang menguntungkan dengan perusahaan besar harus selalu diiusahakan sendiri tanpa harus menunggu jatah atau arahan dari pemerintah. Bantuan pemerintah akan selalu mengungtungkan, tetapi hal itu tidak akan terlalu banyak.

\section{Kesimpulan}

1. Penciptaan linkage industri yang menguntungkan industri kecil hanya dimungkinkan apabila industri besar memiliki interest $\mathrm{ke}$ arah pembinaan basis industri yang luas di dalam negeri. Apabila hal itu tidak menjadi bagian dari tujuan pengusaha besar, maka akan sangat sulit untuk dilaksanakan. Membina usaha kecil di dalam line of bisnis usaha besar, paling tidak akan mengurangi pilihan pengembangan bagi si pengusaha besar. Sampai saat ini, salah satu alasan utama bagi industri besar untuk mengembangkan sistem BAA adalah karena adanya peraturan pemerintah. 
2. Diperlukan sistem pembinaan usaha kecil yang terusmenerus dan dalam waktu yang panjang untuk meningkatkan kualitas produksi. Keterbatasan kemampuan BUMN untuk menangani program ini dapat diatasi dengan mendelegasikannya kepada pihak ketiga, yang dimotori secara ketat oleh pihakpihak yang berkepentingan. Hasil pembinaan itu harus dievaluasi secara baik.

3. Pembinaan industri kecil melalui sistem BAA memerlukan sistem monitoring yang sangat baik. Sistem monitoring yang kurang efektif kemungkinan justru akan menugikan perkembangan industri kecil itu sendiri. Hal ini antara lain disebabkan karena tidak semua pengusaha besar berminat mengembangkan industri kecil menjadi besar atau bcrkembang.

4. Dengan semakin banyak industri-industri raksasa yang berorientasi export dan dengan menggunakan lcbih banyak modal asing, maka peluang keberhasilan pengembangan industri kecil melalui program $\mathrm{BAA}$ akan semakin menyusut. Globalisasi akan memaksa industri-industri besar untuk mempertimbangkan scliap rupiah pengeluarannya secara lebih efisien. Dan ini berarti bertolak belakang dengan arah pengembangan industri kecil.

5. Tekanan perdagangan intemasional dan GATT/WTO akan mengalihkan perhatian pemerintah ke arah industri-industri besar/raksasa, baik domestik maupun asing. Kepentingan industri kecil, apabila tidak terkait secara baik dengan kepentingan industri besar, tidak akan tcrmasuk di dalam domain perhatian pemerintah.
Oleh karena itu secara umum kemandirian industri kecil menjadi lebih masuk akal.

\section{Daftar Pustaka}

Hoesel, Peter van. 1994: "County SME profiles" Proceedings The 21 st Intemational Small Business Congress, Jakarta, September.

Hill, Hal. 1990: Indonesia's Industrial Transformation, Part I, in: Bulletin of Indonesian Economic Studies, Vol.26, no.2, August, pp. 79-120.

, Hal, 1992 (1): Manufacturing Industry; in: Booth (1992), pp.204-257.

, Hal, 1992 (2): Indonesia's Foreign Investment Regime Since 1986: Balancing Economic Imperatives and Political Consraints, in: M. Arsyad Anwar, et.al. (1992), pp.591-615.

Thee, Kian Wie, and Pangestu, Mari, 1993: Technological Dynamism and $R$ \& D Indonesia's Manufactured Exports-Report on Company Interviews. Revised Report for the UNCTAD Project on Technological Dynamism and $\mathrm{R} \$ \mathrm{D}$ in the Exports of Manufactures from Developing Countries, Jakarta, April.

Tjakrawerdaya, S. 1994: "The Role of SMEs in Developing Countries", Proceedings The 21st International Small Business Congress, Jakarta, September.

The World Bank Document (1993): Indonesia Industrial Policy-Shifting into High Gear, September. 